Review

\title{
Constructed Wetlands for Treatment of Combined Sewer Overflow in the US: A Review of Design Challenges and Application Status
}

\author{
Wendong Tao ${ }^{1, *}$, James S. Bays ${ }^{2}$, Daniel Meyer ${ }^{3}$, Richard C. Smardon ${ }^{1}$ and Zeno F. Levy ${ }^{4}$ \\ 1 State University of New York (SUNY) College of Environmental Science and Forestry, \\ 1 Forestry Dr., Syracuse, NY 13210, USA; E-Mail: rsmardon@esf.edu \\ 2 CH2MHILL, 4350 W. Cypress St., Tampa, FL 33607, USA; E-Mail: Jim.Bays@CH2M.com \\ 3 National Research Institute of Science and Technology for Environment and Agriculture \\ (IRSTEA Lyon), 5 rue de la Doua, CS70077, Villeurbanne 69626, France; \\ E-Mail: meyer13@t-online.de \\ 4 Department of Earth Sciences, Syracuse University, 204 Heroy Geology Laboratory, Syracuse, \\ NY 13244-1070, USA; E-Mail: zenolevy@gmail.com \\ * Author to whom correspondence should be addressed; E-Mail: wtao@esf.edu; \\ Tel.: +1-315-470-4928; Fax: +1-315-470-6958.
}

External Editor: Miklas Scholz

Received: 25 August 2014; in revised form: 13 October 2014 / Accepted: 28 October 2014 / Published: 10 November 2014

\begin{abstract}
As combined sewer systems and centralized wastewater treatment facilities age, many communities in the world are challenged by management of combined sewer overflow (CSO). Constructed wetlands are considered to be one of the green infrastructure solutions to CSOs in the US. Despite the wide application of constructed wetlands to different types of wastewaters, the stochastic and intermittent nature of CSO presents challenges for design and performance assessment of constructed wetlands. This paper reviews the application status of CSO constructed wetlands in the US, assesses the benefits of CSO constructed wetlands, identifies challenges to designing CSO constructed wetlands, and proposes design considerations. This review finds that constructed wetlands are effective in CSO treatment and relatively less expensive to build than comparable grey infrastructure. Constructed wetlands not only remove pollutants, but also mitigate the event-associated flow regime. The design challenges include incorporating considerations of green infrastructure into permit requirements, determining design capacity for highly variable flows, requiring pretreatment,
\end{abstract}


and needing adaptive design and intensive monitoring. Simultaneous monitoring of flow rate and water quality at both the inflow and outflow of CSO constructed wetlands is required for performance assessment and needed to support design, but is rarely available.

Keywords: combined sewer overflow; constructed wetland; event-driven wetland; floating wetland island; performance assessment; flow mitigation; wet weather flow; green infrastructure; permit; retention soil filter

\section{Introduction}

More than 700 cities across the US rely on combined sewer systems to collect sanitary sewage, industrial wastewater, and stormwater runoff in the same pipe [1]. Originally, combined sewer systems were designed to convey the combined municipal wastewater for treatment in centralized wastewater treatment facilities. Most of these communities are older cities in the Northeast, the Great Lakes region, and the Pacific Northwest. In the past 50-100 years urban population density and service area of combined sewer systems have been increasing, resulting in higher municipal wastewater flow rates [2]. Moreover, some sewers receive increased groundwater infiltration as the sewer systems age, especially during wet weather periods. Under dry weather conditions, the old combined sewer systems and wastewater treatment facilities are usually able to collect and treat all the combined wastewater. However, wastewater flow may exceed the conveyance capacity of a combined sewer system or the hydraulic capacity of a wastewater treatment facility under wet weather conditions, especially during highintensity storm and snowmelt events, resulting in combined sewer overflow (CSO). CSO is a mixture of sewage, stormwater inflow, industrial effluent, and infiltration, which is directly discharged from combined sewers or passes by a wastewater treatment facility to nearby water bodies. Climate change could further amplify the CSO issue due to shorter return periods of extreme storm events [1,2].

The CSO events introduce pollutants from both sanitary wastewater and stormwater runoff, such as oxygen-demanding substances, nutrients, and pathogens. CSO discharges are a major water pollution concern for the US cities having combined sewer systems [1]. The CSO outfalls are considered to be point sources of pollution, and thus are regulated under Section 402 of the US Clean Water Act. Consequently, CSOs are subjected to the permit program of the National Pollution Discharge Elimination System (NPDES), which sets technology-based treatment standards and water quality-based effluent limits. The initial CSO Control Policy released by the US Environmental Protection Agency (USEPA) in 1994 allowed state NPDES permitting authorities to use "best professional judgment" to ensure CSO communities develop long-term control plans that evaluate alternatives for attaining compliance with the Clean Water Act [3]. In 2000, Congress amended section 402 of the Clean Water Act to require both NPDES permits and enforcement orders for CSO discharges [1]. Meanwhile, the controls have focused on maximizing wet weather flows to publicly-owned wastewater treatment facilities and enhancing traditional grey infrastructure, such as underground storage tanks and regional CSO treatment facilities [4]. Recently, there has been a movement in CSO management policy and practice to support green infrastructure technologies for mitigation of wet weather discharges [1,5]. The USEPA [1] describes CSO control technologies in four 
groups: operation and maintenance practices; collection system controls including conventional approaches and green infrastructure; storage facilities; and treatment technologies. Constructed wetlands (CWs) are green infrastructure for both flow mitigation and treatment of CSOs [1,6,7].

CSO treatment in CWs has been permitted by State permitting authorities with provisions in attachments to the discharge permits of several centralized wastewater treatment plants [8,9]. Integration of CWs into CSO control plans is a sustainable practice in that it reduces energy consumption, carbon footprint, and economic cost compared with traditional wastewater treatment methods [6,7]. Additionally, CWs may provide various other ecosystem services [1,7,10]. Successful operation of CWs has been reported from the tropics to the Arctic for treatment of a variety of wastewaters including sanitary wastewater and stormwater. The contaminants being effectively removed in CWs range from conventional pollutants such as total suspended solids (TSS), biochemical oxygen demand (BOD), ammonia, total Kjeldahl nitrogen (TKN), nitrate, total phosphorus (TP), and pathogens; to such priority pollutants as heavy metals and chlorinated organic compounds [7].

In terms of average water quality, CSO falls between sanitary wastewater and stormwater runoff (Table 1). However, the stochastic and intermittent nature of both CSO flow and pollutant loading demand further exploration into design considerations for CSO CWs. Treatment of CSO discharges using either conventional methods or CWs must be designed to be simple, rugged, and reliable despite highly variable influent flow rates and pollutant concentrations [2]. This highlights special challenges in $\mathrm{CW}$ applications because they are natural treatment systems, which are subjected to the varying environmental conditions and often provide additional ecosystem services.

Table 1. Characteristics of combined sewer overflow (CSO) in comparison with municipal wastewater and stormwater in the US.

\begin{tabular}{|c|c|c|c|c|}
\hline \multirow[b]{2}{*}{ Parameter } & \multicolumn{2}{|c|}{ Combined Wastewater } & \multirow{2}{*}{$\begin{array}{c}\text { Municipal } \\
\text { Wastewater } \\
{[2,7]}\end{array}$} & \multirow{2}{*}{$\begin{array}{c}\text { Urban } \\
\text { Stormwater } \\
\text { Runoff }[2,7]\end{array}$} \\
\hline & Typical [2] & $\begin{array}{c}\text { Monitoring at Harbor } \\
\text { Brook, Syracuse, NY [11] }\end{array}$ & & \\
\hline $\mathrm{BOD}_{5}(\mathrm{mg} / \mathrm{L})$ & $60-220$ & $30-41$ & $110-400$ & $7-56$ \\
\hline TSS (mg/L) & $270-550$ & $73-167$ & $100-400$ & $20-2890$ \\
\hline Ammonia-N (mg/L) & Unavailable & $0.47-0.94$ & $12-50$ & 0.58 \\
\hline TKN (mg/L) & $4-17$ & $4.0-7.8$ & $20-85$ & $0.4-4.2$ \\
\hline Nitrate $(\mathrm{mg} / \mathrm{L})$ & $0.48-0.91$ & 0.22 & 0 & $0.05-1.0$ \\
\hline $\mathrm{TP}(\mathrm{mg} / \mathrm{L})$ & $1.2-2.8$ & $0.8-2.2$ & $4-20$ & $0.02-4.3$ \\
\hline Fecal coliforms $(\# / 100 \mathrm{~mL})$ & $10^{5}-10^{6}$ & $4.0 \times 10^{5}$ & $10^{5}-10^{8}$ & $10^{3}-10^{4}$ \\
\hline
\end{tabular}

Although CWs have been widely used for CSO treatment in European countries such as Germany, France, and Italy [12], there is little performance data available to support design in the US. Monitoring campaigns in Europe have been implemented as research programs, but results have not been published internationally. Pre- and post-construction monitoring is generally not required yet, although data collection in advance to the layout process might become mandatory in France soon. There are only a few pilot- and full-scale CWs for CSO treatment in the US. This paper reviews CSO CW applications in the US, evaluates primary benefits of CSO CWs, identifies design challenges associated with the stochastic and intermittent nature of CSOs, and proposes design considerations and performance assessment methods for CSO CWs. The Harbor Brook CSO CW Treatment Facility in Syracuse, NY is 
taken as an example to demonstrate how an adaptive design approach was used to deal with the challenges associated with event-feeding of CSO CWs and to create a demonstration of possible $\mathrm{CW}$ technologies to inform future implementation.

\section{Status of Constructed Wetlands for CSO Treatment in the US}

Design parameters of CWs are determined mostly based on performance data of existing treatment wetlands. However, there are only a few CWs designed and operated to treat CSO in the US (Table 2). Recently, wetland treatment systems have been included in long-term CSO control plans such as in Evansville, Indiana and Syracuse, New York $[13,14]$. A comprehensive review of these existing systems will facilitate designs for future applications.

Table 2. Wetland treatment systems receiving combined sewer overflow in the US.

\begin{tabular}{|c|c|c|c|c|c|}
\hline $\begin{array}{c}\text { Name of CSO CW } \\
\text { and Data Source }\end{array}$ & Minoa $[15,16]$ & $\begin{array}{c}\operatorname{Arch} / \text { Bar } \\
{[17]} \\
\end{array}$ & $\begin{array}{c}\text { Akron } \\
{[5,18]} \\
\end{array}$ & $\begin{array}{c}\text { Washington } \\
{[19,20]} \\
\end{array}$ & $\begin{array}{c}\text { Harbor Brook } \\
{[21]}\end{array}$ \\
\hline Year of construction & 1995 & 1999 & 2001 & 2010-2012 & $2012-2014$ \\
\hline Design storm event & $\mathrm{n} / \mathrm{a}$ & $\begin{array}{l}\text { First flush } \\
\text { (40 min) }\end{array}$ & $\mathrm{n} / \mathrm{a}$ & $\begin{array}{l}\text { 10-yr 1-h } \\
\text { (excluding } \\
\text { first flush) }\end{array}$ & $1-y r 2-h$ \\
\hline $\begin{array}{c}\text { Design CSO volume } \\
\left(\mathrm{m}^{3} / \text { event }\right)\end{array}$ & $1053^{a}$ & 52 (Typical) & 1890 & 79,380 & 2640 \\
\hline $\begin{array}{c}\text { Design peak CSO } \\
\text { flow rate }\left(\mathrm{m}^{3} / \mathrm{h}\right) \\
\end{array}$ & 101 & 250 (Typical) & $\mathrm{n} / \mathrm{a}$ & 2019 & 4485 \\
\hline Pretreatment & Primary clarifier & $\begin{array}{c}\text { Bar screen \& } \\
\text { sedimentation } \\
\text { basin }\end{array}$ & $\begin{array}{c}\text { Swirl } \\
\text { separation } \\
\text { units } \\
\end{array}$ & $\begin{array}{l}\text { Storage tank, } \\
\text { nutrient baffle } \\
\text { box, and pond }\end{array}$ & $\begin{array}{c}\text { Swirl separation } \\
\text { unit }\end{array}$ \\
\hline Wetland area $\left(\mathrm{m}^{2}\right)$ & 4500 & 2023 & 24,281 & 109,265 & 3139 \\
\hline $\begin{array}{l}\text { Wetland system } \\
\text { components }\end{array}$ & $\begin{array}{c}3 \text { subsurface } \\
\text { flow wetlands in } \\
\text { series }\end{array}$ & $\begin{array}{l}\text { FWS wetland- } \\
\text { vertical flow } \\
\text { wetland series }\end{array}$ & $\begin{array}{c}2 \text { FWS } \\
\text { wetlands in } \\
\text { parallel }\end{array}$ & $\begin{array}{l}\text { FWS wetland- } \\
\text { gravel filter series }\end{array}$ & $\begin{array}{l}\text { Floating island, } \\
\text { vertical flow, \& } \\
\text { FWS wetlands }\end{array}$ \\
\hline Effluent disinfection & $\begin{array}{l}\text { Chlorination/ } \\
\text { dechlorination }\end{array}$ & No & No & Ultraviolet & $\mathrm{No}^{\mathrm{b}}$ \\
\hline $\begin{array}{l}\text { Event hydraulic } \\
\text { loading depth } \\
\text { (mm/event) }\end{array}$ & 234 & 26 & 78 & 726 & 841 \\
\hline Receiving waters & River & River & Lake & Creek & Creek \\
\hline
\end{tabular}

\subsection{Harbor Brook CSO Constructed Wetlands in City of Syracuse, New York}

The Harbor Brook CSO Constructed Wetland Treatment Facility was built in Syracuse, New York as an integral part of Onondaga County's "Save the Rain" green infrastructure program. It consists of a swirl/vortex separation unit for grit and floatable removal and three CWs for further treatment. CSO 
flows between 611.6 and $4485 \mathrm{~m}^{3} / \mathrm{h}$ at discharge point 018 are diverted to the separators. The pre-treated CSO overflows to three CWs, i.e., detention basin with an open cover of floating wetland islands (Cell 1), vertical flow wetland (Cell 2), and FWS wetland (Cell 3) (Figure 1). The three CWs can be operated in three different flow sequences, i.e., series, parallel, and series/parallel.

Figure 1. Layout of Harbor Brook CSO constructed wetlands in series/parallel operation with pictures showing pre-operation status. The pictures were taken by W. Tao, showing the floating island wetland with three vegetated floating mats (a); vertical flow wetland with white risers over concrete splash pads (b); and a deep water zone and vegetation of the free water surface wetland (c).

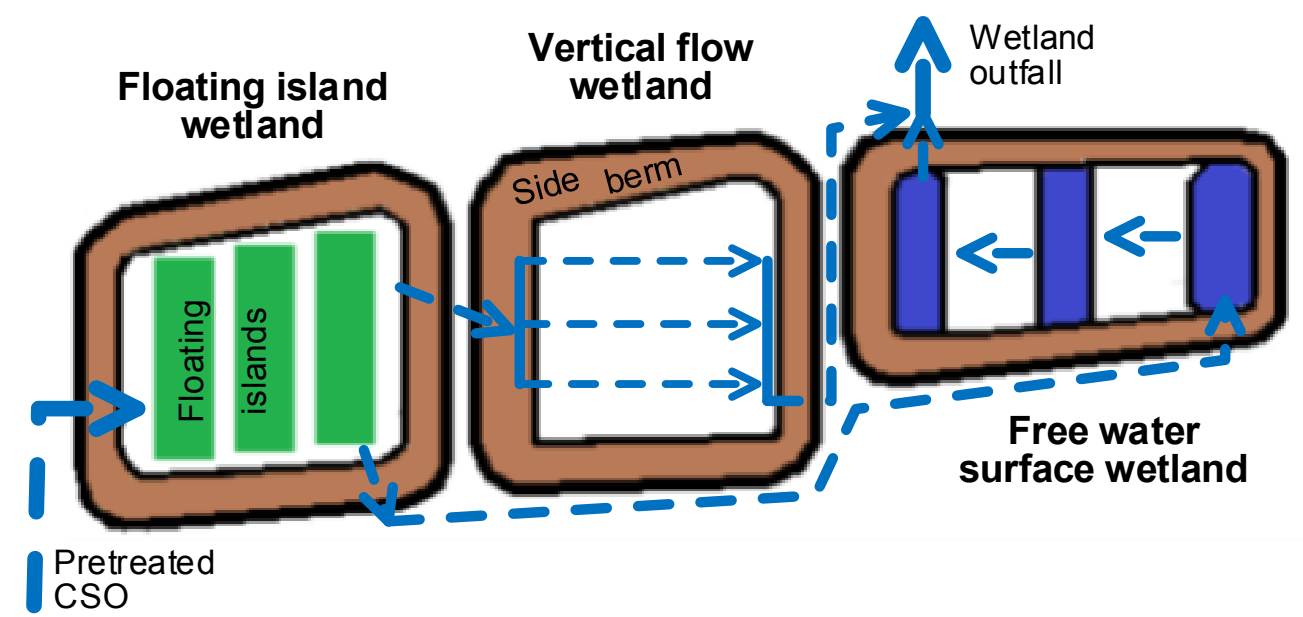

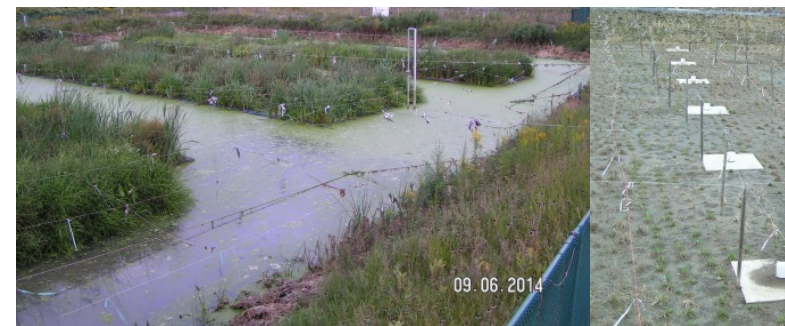

(a) (b)

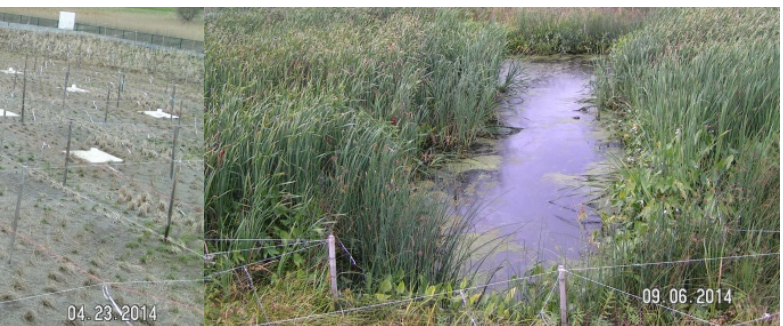

(c)

The floating island wetland has a total surface area of $1135 \mathrm{~m}^{2}$. It has three arrays of floating wetland islands planted with diverse native species and anchored laterally to the side berms [21]. It is designed to have a normal water depth of $0.3 \mathrm{~m}$ and a maximum event depth of $1.2 \mathrm{~m}$. The bottom of this wetland is lined with a high-density polyethylene liner. The sides are lined with clay liner with $0.15 \mathrm{~m}$ of topsoil above the liner.

The FWS wetland has a total surface area of $1023 \mathrm{~m}^{2}$. It has two vegetated shelves and three $0.9 \mathrm{~m}$ deep water zones. The shelves were planted with broadleaf cattails and rushes. This wetland is not lined so that its deep water zones could be recharged by groundwater. The normal water depth above the shelves is $0.15 \mathrm{~m}$ and maximum event depth is $0.46 \mathrm{~m}$. Stop logs in the outlet structure allow $0.15 \mathrm{~m}$ of standing water within this wetland.

The vertical flow wetland has an area of $981 \mathrm{~m}^{2}$, which is packed with a layer of sand overlying a layer of gravel to a total media depth of $0.8 \mathrm{~m}$ (Figure 2). When in parallel operation with the other two wetlands, CSO is loaded continuously to the sand-gravel bed. Water percolates down through the bed and is discharged through an underdrain. When in series and series/parallel operations, it is operated by 
batch, with Cell 1 dosing $208 \mathrm{~m}^{3}$ to Cell 2 using an automated control valve via 18 risers for approximately $2 \mathrm{~h}$ and then resting for $4 \mathrm{~h}$ in each cycle. When in series/parallel operation, the "top half" of the Cell 1 storage is sent to Cell 3, allowing Cell 3 to drain into Harbor Brook prior to dosing Cell 2. This dosing and resting cycle occurs nine times following a 1-yr 2-h storm event. Normally there will be no standing water on the surface, although the maximum ponding depth can be $0.15 \mathrm{~m}$. The vertical flow wetland was planted with native wetland plant species that tolerate both flooding and drought.

Figure 2. Vertical configuration of Harbor Brook vertical flow constructed wetland. Modified from CH2MHILL and CHA [22].

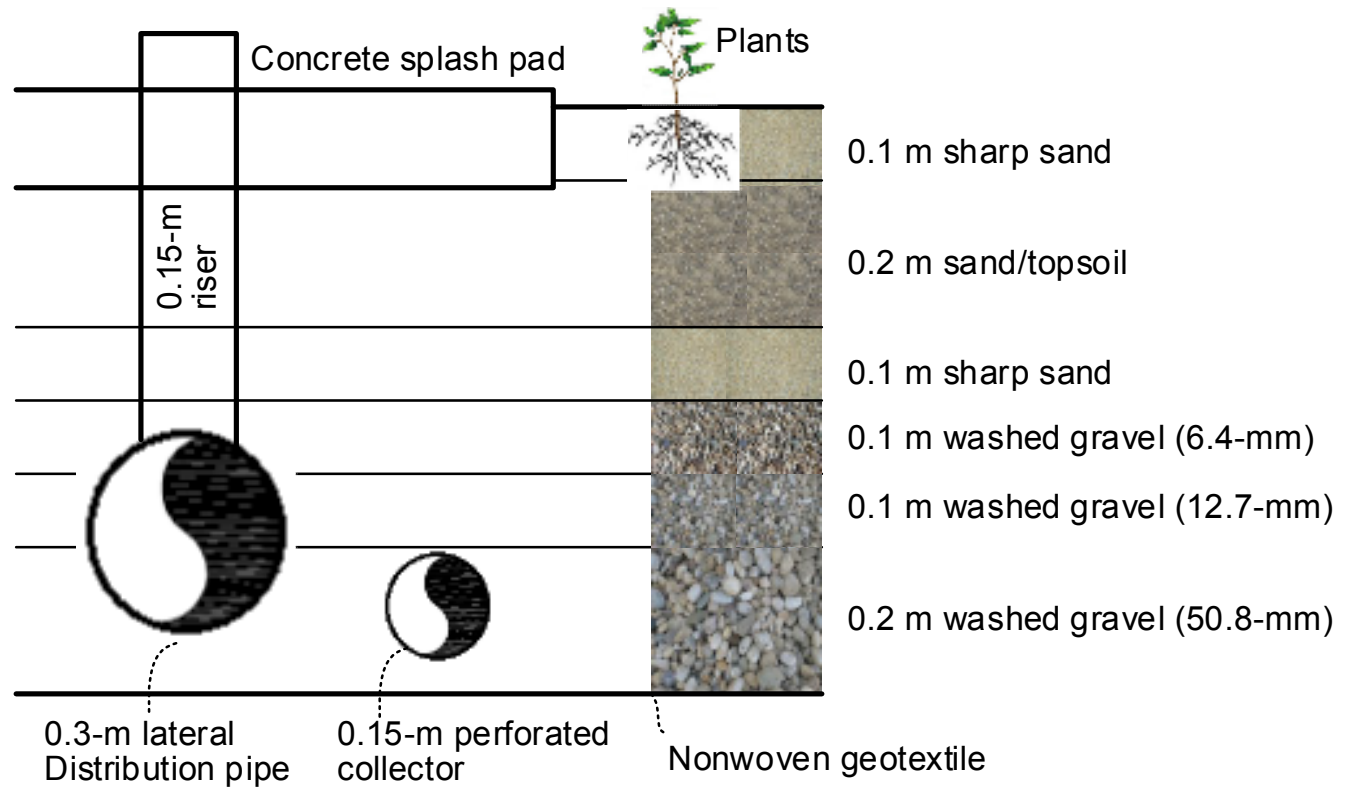

Wetland effluent will be discharged through a single outfall (018) to Harbor Brook. The Harbor Brook CSO 018 Constructed Wetland Treatment Facility is considered to be a CSO treatment facility in the State discharge permit NY 0027081 to Metropolitan Syracuse Wastewater Treatment Plant. The permit only requires monitoring of the wetland treatment system's influent and effluent. As a pilot project, the inflow and outflow of each wetland will be monitored intensively during CSO events and weekly between CSO events over two years starting in October 2014. Automated samplers and flow meters will be installed to record flow regime and collect water samples in addition to grab samples and in-situ measurements.

\subsection{Minoa Constructed Wetlands in Village of Minoa, New York}

The Village of Minoa in Onondaga County, New York had a combined sewer system serving more than 3300 residents. Its wastewater treatment facility has three subsurface flow CWs. Start-up occurred in June 1995 using secondary effluent from this facility's trickling filters. In January 1996, the wetland started to treat primary effluent. The wetlands were originally built to handle wet weather flows [15,23], thus being the first CSO CWs in the US. The facility's permitted flow was $2079 \mathrm{~m}^{3} / \mathrm{d}$ for dry weather flow and $3402 \mathrm{~m}^{3} / \mathrm{d}$ for wet weather flow [23]. Actually, the CWs have been operated year-round to treat both dry and wet weather flows. 
The treatment capacity of the $4500 \mathrm{~m}^{2}$ wetlands was $491 \mathrm{~m}^{3} / \mathrm{d}[15,16]$. The top $0.1 \mathrm{~m}$ of the medium bed was $0.6 \mathrm{~cm}$ pea gravel and served as the rooting medium for emergent plants. The $0.6 \mathrm{~m}$ of treatment zone in the bed was packed with $1.9 \mathrm{~cm}$ washed and screened coarse gravel. High-density polyethylene liners were used to divide each wetland into two cells planted with Phragmites and Scirpus species, respectively. Later on, the Scirpus species was removed and no significant difference in treatment performance was found between the planted and unplanted cells in parallel operation. The three CWs were operated in series in 1996 and 1997. The wastewater contained about $50 \mathrm{mg} / \mathrm{L}$ of sulfate, and the wetland water became anaerobic after a few hours of loading in 1996 [15]. The wetland effluent BOD concentration during the spring and summer of 1996 was $84 \mathrm{mg} / \mathrm{L}$, which was above the design objective of $30 \mathrm{mg} / \mathrm{L}$ [15]. The operation was then switched in April 1997 from continuously fed horizontal flow subsurface wetlands at water depths of $0.5-0.9 \mathrm{~m}$ to vertical flow wetlands utilizing in a fill-draw mode of operation. Starting from April 1998, wetlands 1 and 2 were in series with wetland 3 [16]. It took $4-5 \mathrm{~h}$ to drain wetlands 1 and 2 and $24 \mathrm{~h}$ to refill [15]. Consequently, the media beds were exposed to aerobic conditions for up to $20 \mathrm{~h}$ per cycle of operation.

The wetland effluent is discharged to Limestone Creek through one outfall after disinfection and dechlorination along with the effluent of its trickling filters and sequencing batch reactors. The Village of Minoa phased out the combined sewer system in 2005-2007. Therefore, the operating data after 2005 no longer reflect the performance of CSO wetlands.

\subsection{Arch/Bar CSO Constructed Wetlands in Town of Elkhart, Indiana}

The CSO wetland treatment system located at Arch and Bar streets in Elkhart, Indiana was constructed as a demonstration of an alternative to CSO separation. It has been operated to treat first flush discharged at CSO 5. It is unclear about the design duration of first flush, but appears to be the first 40 min of CSO [17]. It is permitted by the Indiana Department of Environmental Management (IDEM) as Outfall \#5 of NPDES Permit IN0025674 to Elkhart Wastewater Treatment Plant [8]. The Arch/Bar wetland system has a free water surface (FWS) wetland with an active littoral habitat and micropool graded below the groundwater table, followed by a vertical flow wetland (Figure 3). Nearly 30 different species of native aquatic and transitional vegetation were strategically planted for ecological competitive advantage [17].

Figure 3. Layout of Arch/Bar CSO constructed wetland at Elkhart, Indiana. Source: modified from a figure in Umble et al. [17] with permission from Watershed Management 2000 Conference, Copyright (C) 2000 Water Environment Federation, Alexandria, Virginia.

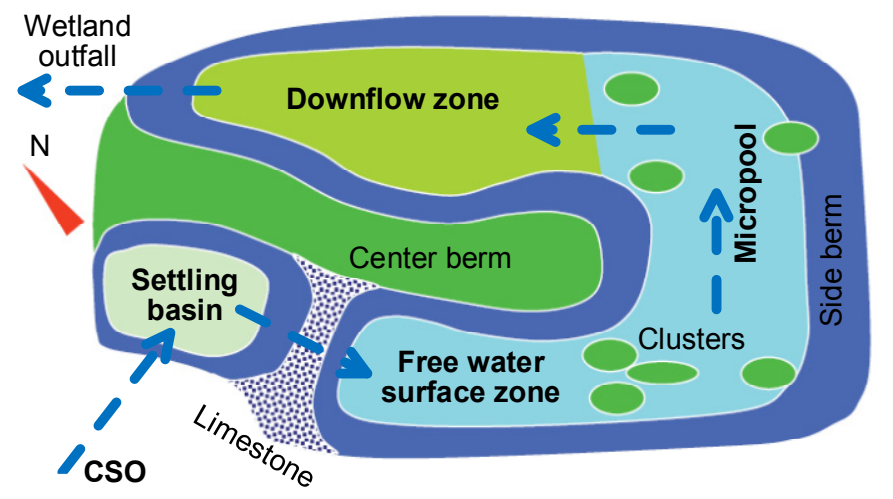


Wetland effluent is discharged to Elkhart River without disinfection. Only monthly visual flow monitoring is required by its permit [8]. The compliance monitoring from September 2007 to May 2014 showed no CSO discharge except for two events in September 2008 at a total flow of $11.7 \mathrm{~m}^{3}$ in $2.74 \mathrm{~h}$ [8]. September 2008 had a total precipitation of $254.3 \mathrm{~mm}$.

\subsection{Akron CSO Constructed Wetlands in Town of Akron, Indiana}

The Town of Akron in Fulton County, Indiana has a combined sewer system with three CSO discharge points. A CW treatment system was designed to treat certain wet weather flows from two CSO points [24]. The system was completed and began operation in 2001. This CSO wetland treatment system is permitted as two outfalls (\#501 and \#502) of the Akron Municipal Wastewater Treatment Plant by NPDES Permit IN0025232 [8]. The CSO discharges from two CSO points undergo grit and floatable removal in swirl separators, which then flow through two serpentine earthen FWS wetlands [5]. There are rock filtration structures at the inlet and outlet of the wetlands to help remove debris [18].

The CWs discharge to a field tile, which enters Town Lake [24]. An agreed order in 2003 [24] stated that the influent channels to both the CWs shall be monitored for CSO diversion occurrence and monitor wetland effluent for $\mathrm{pH}$, ammonia, TSS, 5-day carbonaceous BOD (CBOD5), dissolved oxygen, Escherichia coli, phosphorus, and flow. However, monthly monitoring started in November 2007 for $\mathrm{CW} \# 1$ and \#2 and only influent flow rate data have been reported for permit compliance [8].

\subsection{Washington CSO Constructed Wetlands in City of Washington, Indiana}

The Washington wetland treatment system is the largest CSO CW treatment system in the US. It is located in the City of Washington, Daviess County, Indiana. The City of Washington has a combined sewer system with five active CSO outfalls. The City of Washington commissioned this wetland treatment system to battle an extremely sensitive combined sewer system, which discharged CSO during rainfall events as little as $2.5 \mathrm{~mm}$ of rainfall [20]. The wetland treatment system consists of a nutrient baffle box, a 15,120 $\mathrm{m}^{3}$ forebay pond, a serpentine FWS wetland, a gravel filter, and a UV disinfection system at the outfall (Figure 4). The FWS wetland was lined with ethylene propylene diene monomer liner and planted with more than 30 emergent and submerged species. The CSO is filtered into an $18,900 \mathrm{~m}^{3}$ storage tank. The first flush is sent to the municipal wastewater treatment plant, while any overflow up to that initiated by the 10-yr 1-h storm is diverted to the CWs [19,20]. Wetland discharge at Outfall 010 is permitted with provisions in Attachment A of NPDES Permit IN0025658 to the Washington Waste Water Treatment Plant [8].

The Washington CWs discharge to the nearby Hawkins Creek. The NPDES Permit has mass-based effluent limitations for CBOD5, TSS, and ammonia. Daily wetland monitoring was started in January 2013 [8]. Monthly average and daily maximum values of composite and grab samples are reported for wetland effluent. There are no data reported on the wetland influent. Because of the equalization effects of the large storage tank and forebay pond, the Washington CSO CWs exhibited little variation in daily effluent flow rate (Figure 5). 
Figure 4. Layout of Washington CSO wetland treatment system. Source: Drawing with reference to Google Map at maps.google.com on 12 August 2014 and description by Harrison and Kasthuri [19].

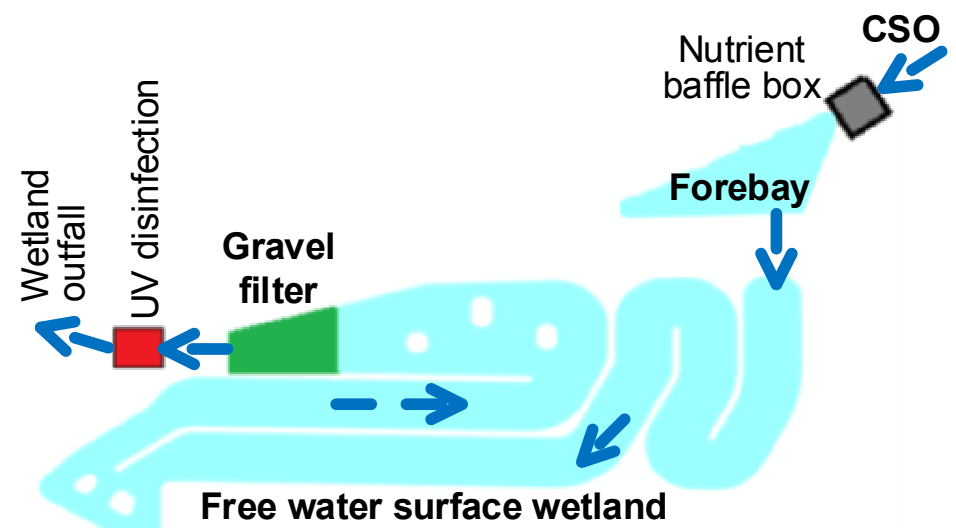

Figure 5. Effluent flow rate and quality of Washington CSO wetland treatment system. Data source: USEPA [8]. Horizontal red lines are permit limits for E. coli.
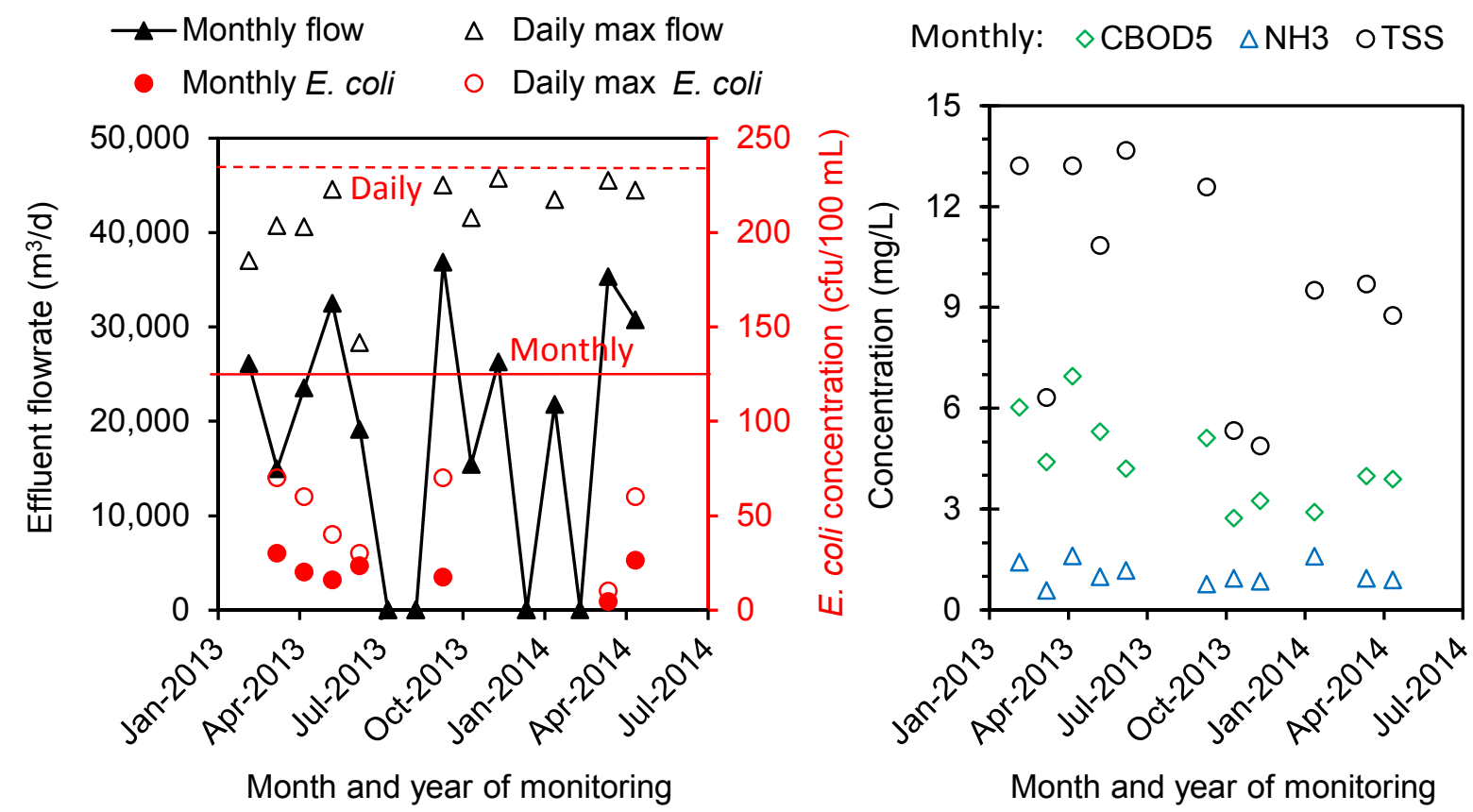

\subsection{Benefits Demonstrated by Existing CSO Constructed Wetlands}

Full-scale CWs are cost-effective green infrastructure solutions to mitigating CSO flow and improving water quality. Although there are fewer CSO CW treatment systems in the US at this time, the benefits of CWs are clear.

The CWs decrease capital cost of CSO treatment compared with conventional grey infrastructure technologies. CWs are designed as ecologically engineered treatment systems, minimizing the use of mechanical elements and automated controls while maximizing the use of low-cost, locally available materials such as excavated topsoil, sand, gravel, plants, and clay liner. The entire Akron CSO CW treatment system cost $\$ 0.7$ million, an economical alternative to $\$ 5.1$ million to separate the sewer 
system and enlarge the municipal wastewater treatment plant [18]. The Washington CW project was able to reduce CSO treatment costs from an estimated $\$ 40$ million to $\$ 26.4$ million [20]. The unit capital cost of the Washington wetland treatment system was estimated to be $\$ 2.28 / \mathrm{m}^{3}$ compared to $\$ 4.63 / \mathrm{m}^{3}$ for sewer separation and physical/chemical treatment [19]. The Harbor Brook CW treatment project had a total cost of $\$ 4,519,790$ [14]. It was designed to treat approximately $55,944 \mathrm{~m}^{3} / \mathrm{yr}$ of CSO. Assuming a $40 \mathrm{yr}$ project life, the present unit capital cost of the Harbor Brook wetland project was approximately $\$ 2.02 / \mathrm{m}^{3}$, which is similar to that of the Washington wetland treatment system. The total cost of Minoa CWs was $\$ 568,000$ in 1995 at a design flow rate of $491 \mathrm{~m}^{3} / \mathrm{d}$ [16]. Even considering the different years of construction, the unit cost is much lower at Minoa in comparison to Washington and Harbor Brook, which may be attributed to the presence of pretreatment at Minoa. A comprehensive review by Kadlec and Wallace [7] showed an average areal capital cost of the CWs in the US at approximately $\$ 1.0 \mathrm{million} / \mathrm{ha}$ in 2006 value. Nevertheless, the cost of CWs was not reported separately from the pretreatment facility for the existing CSO wetland treatment systems in the US. In addition to the lower capital cost, operation and maintenance costs for a treatment wetland are typically much lower than that for competing technologies [7].

The CWs are designed to maximize utilization of natural processes and ecosystem functions. When used for wastewater treatment, comparatively slow natural processes supported by natural sources of renewable energy and self-organization of ecosystems are typically offset by larger areas or longer retention of wastewater. Consequently, CWs can better accommodate the highly variable flow rate of CSOs compared with conventional wastewater treatment facilities. The larger CSO storage capacity of CWs contributes to both water quality improvement and flow mitigation. The CSO flow mitigation in CWs can be attributed to retention of peak flow during CSO overflow periods followed by volume reduction over long periods of evapotranspiration, evaporation, and possibly seepage to groundwater. The CSO CWs in the US have demonstrated an excellent capacity to handle peak flow and abate CSO volume. There were about 20-25 CSO events annually in Akron [18]. However, there was only one discharge from the Akron CSO CWs on 11 July 2003 between its start in fall 2001 and October 2003 [24]. Based on the maximum weekly flow measurements of Akron CSO wetland influent and its design CSO volume, it is estimated that the two wetlands only discharged in approximately 37 weeks between October 2007 and April 2014 (Figure 6). The floating island and FWS wetlands at Harbor Brook can store CSO inflow up to 1362 and $471 \mathrm{~m}^{3}$, respectively. Modeling of the Harbor Brook CWs showed that the wetlands would be unable to store the CSO overflow in only six out of 42 events in an average year (Figure 7).

The CSO CWs in the US are mostly not assigned numeric limits (Table 3). There are few monitoring results reported for the existing CSO CWs. When comparing wetland effluent concentrations with permit limits for the main outfall of their associated central wastewater treatment plants (Table 4), it appears that the CSO CWs could safely meet the most stringent CBOD 5 limit (monthly average $20 \mathrm{mg} / \mathrm{L}$ ), the monthly TSS limits, and possibly the ammonia limits with only a few violations. The BOD removal efficiency of the Minoa subsurface flow wetlands during the fill-draw mode of operation in 1997 was 95\% on average, and effluent BOD was less than $15 \mathrm{mg} / \mathrm{L}[15,16]$. The influent and effluent of the Arch/Bar CSO CWs were monitored in 1999 and 2000 using automated flowmeters and automatic samplers. The average removal efficiency was $91 \%$ chemical oxygen demand, $92 \%$ TSS, $98 \%$ ammonia, 96\% TP, and 5-6 log of E. coli [17], suggesting low effluent concentrations considering the CSO 
concentration ranges (Table 1). The Washington CWs have had effluent CBOD5 and TSS concentrations (Figure 5) lower than the limits for the main outfall of Washington municipal wastewater treatment plant. However, ammonia concentration in the wetland effluent (Figure 5) exceeded the limit for the main outfall in three out of 13 months. The effluent $E$. coli concentrations of the Washington wetland treatment system (Figure 5) have been much lower than its limits due to its ultraviolet disinfection system. The Washington CWs did not show a seasonal change in effluent quality (Figure 5) despite its snowy winter from December to March.

Figure 6. Maximum weekly CSO inflow to Akron constructed wetlands. Green dash line represents the weekly flow to meet the design CSO volume in a week. 24 values smaller than 1 are not shown in the log graph. Data source: USEPA [8].

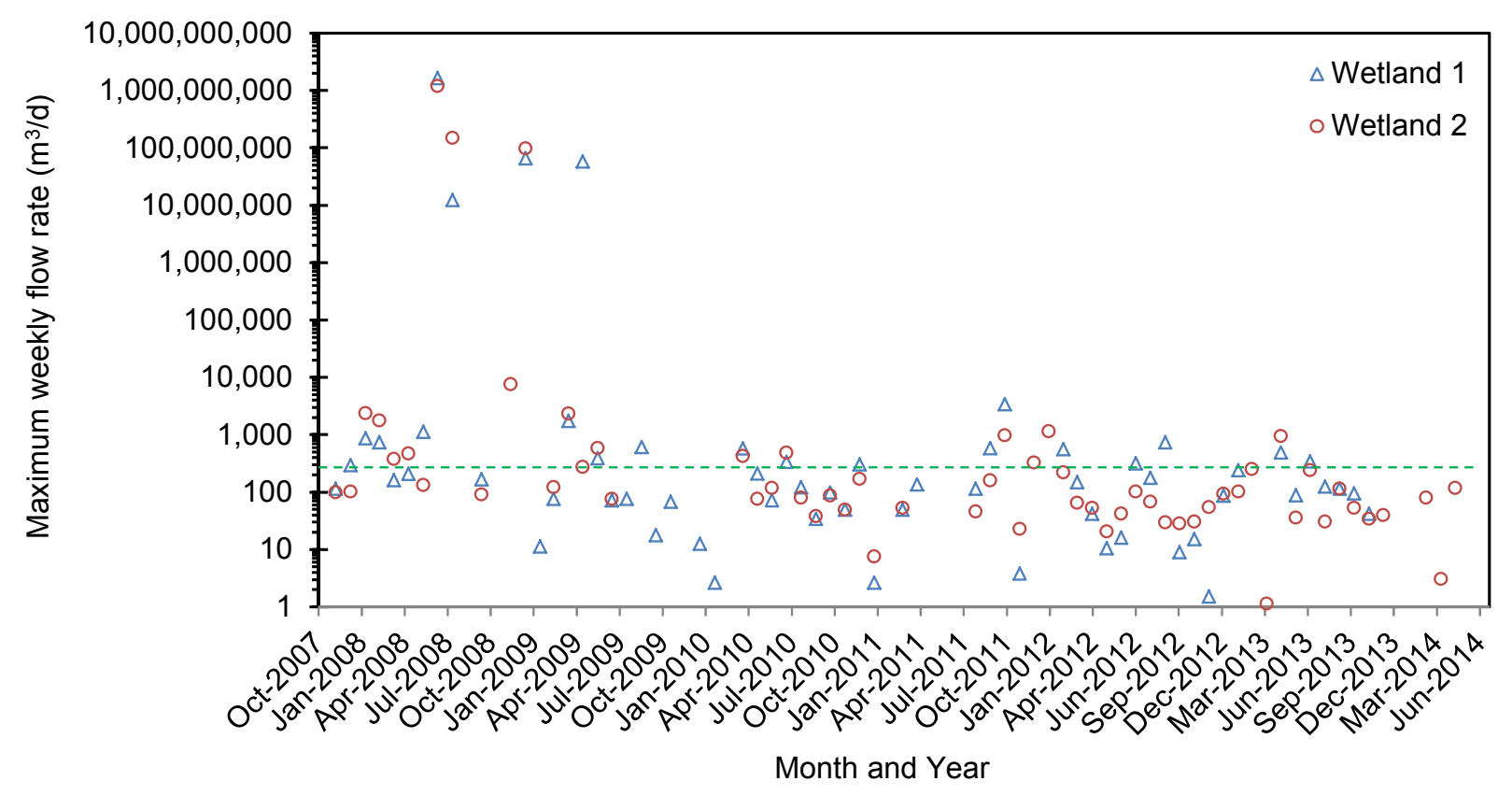

Figure 7. Event volume of CSO overflow from a grit removal unit to Harbor Brook constructed wetlands in an average year. Data source: CH2MHILL and CHA [21].

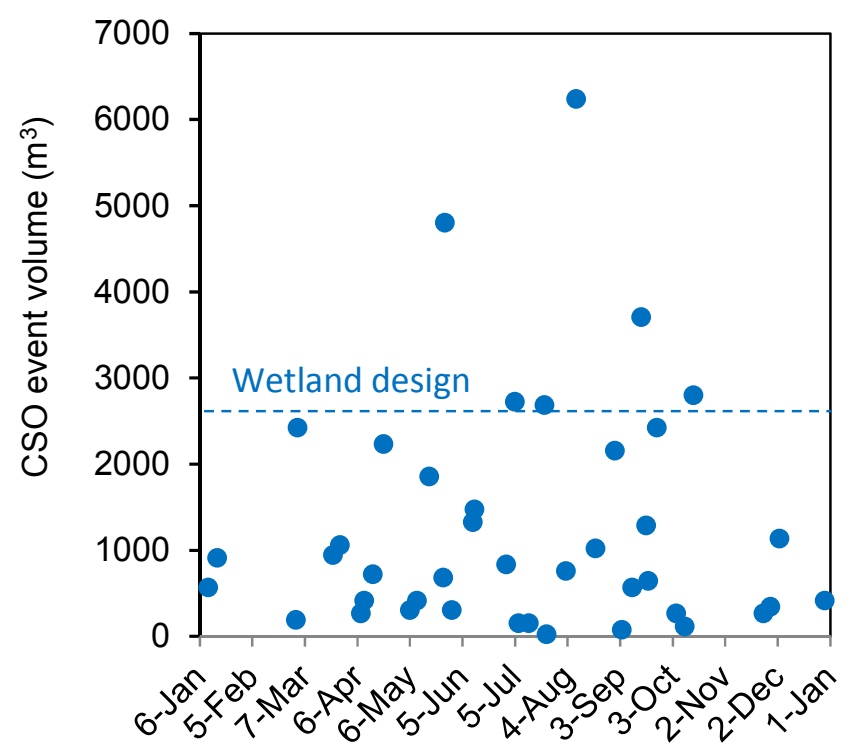


Table 3. Current permit limits for CSO constructed wetland effluent in the US *.

\begin{tabular}{|c|c|c|c|c|}
\hline Monitoring Parameter & Arch/Bar CWs [8] & Akron CWs [8] & $\begin{array}{c}\text { Washington } \\
\text { CWs [8] }\end{array}$ & $\begin{array}{c}\text { Harbor Brook } \\
\text { CWs [9] } \\
\end{array}$ \\
\hline Flow & Visual monitoring & Report* & Report & Report \\
\hline $\begin{array}{l}\mathrm{pH} \text {, dissolved oxygen, } \mathrm{CBOD}_{5}, \\
\mathrm{TSS} \text {, and total phosphorus }\end{array}$ & & & Report & Report \\
\hline $\mathrm{NH}_{3}$ & & & Report & Report \\
\hline TKN & & & & Report \\
\hline Total nitrogen and $\mathrm{NO}_{3}^{-}$ & & & Report & \\
\hline E. coli $(\mathrm{cfu} / 100 \mathrm{~mL})$ & & & $\begin{array}{l}\text { Monthly } 125 ; \\
\text { daily max } 235\end{array}$ & \\
\hline Fecal coliforms $(\mathrm{cfu} / 100 \mathrm{~mL})$ & & & & 200/Event \\
\hline
\end{tabular}

Notes: * "Report" means that monitoring is required, but no numeric limits are set.

Table 4. Current permit limits for the main outfall of centralized wastewater treatment plants with off-plant CSO constructed wetlands in the US.

\begin{tabular}{|c|c|c|c|c|}
\hline $\begin{array}{l}\text { Monitoring } \\
\text { Parameter }\end{array}$ & $\begin{array}{c}\text { Elkhart WWTP } \\
\text { (Compared with } \\
\text { Arch/Bar } \\
\text { Wetlands) }\end{array}$ & $\begin{array}{c}\text { Akron Municipal } \\
\text { WWTP } \\
\text { (Compared with } \\
\text { Akron Wetlands) }\end{array}$ & $\begin{array}{c}\text { Washington WWTP } \\
\text { (Compared with } \\
\text { Washington } \\
\text { Wetlands) }^{\text {a }}\end{array}$ & $\begin{array}{c}\text { Metro Syracuse } \\
\text { WWTP (Compared } \\
\text { with Harbor Brook } \\
\text { Wetlands) }^{\text {a }}\end{array}$ \\
\hline Flow $\left(\mathrm{m}^{3} / \mathrm{d}\right)$ & Report & $\begin{array}{c}\leq 1 / 10 \text { receiving } \\
\text { stream }\end{array}$ & Report & $4.77 \times 10^{5}$ \\
\hline $\mathrm{pH}$ & DA 6-9 & DA 6-9 & DA 6-9 & $6-9$ \\
\hline $\begin{array}{c}\text { Dissolved oxygen } \\
(\mathrm{mg} / \mathrm{L})\end{array}$ & $\mathrm{DA} \geq 4$ & $\mathrm{DA} \geq 6$ & $\mathrm{DA} \geq 5-6$ & \\
\hline $\mathrm{CBOD}_{5}(\mathrm{mg} / \mathrm{L})$ & MO 25; WK 40 & MO 25; WK 40 & MO 20-25; WK 30-40 & MO 21; WK 31.5 \\
\hline $\mathrm{TSS}(\mathrm{mg} / \mathrm{L})$ & MO 30; WK 45 & MO 105; WK 70 & MO 20-25; WK 30-40 & MO 30; WK 45 \\
\hline $\mathrm{NH}_{3}(\mathrm{mg} / \mathrm{L})$ & MO 5.3; WK 12.4 & Report & MO 1.5; WK 2.4 & $\begin{array}{c}\text { MO } 1.2 \\
\text { (June-October); } \\
2.4 \\
\text { (November-May) } \\
\end{array}$ \\
\hline TKN (mg/L) & & & & Report \\
\hline $\mathrm{NO}_{3}{ }^{-}(\mathrm{mg} / \mathrm{L})$ & & & & Report \\
\hline $\mathrm{TP}(\mathrm{mg} / \mathrm{L})$ & MO 1.0 & & & 12-month rolling 0.10 \\
\hline E. coli $(\mathrm{cfu} / 100 \mathrm{~mL})$ & MO 125; DA 235 & MO 125; DA 235 & MO 125; DA 235 & \\
\hline $\begin{array}{l}\text { Fecal coliforms } \\
(\mathrm{cfu} / 100 \mathrm{~mL})\end{array}$ & & & & MO 200; WK 400 \\
\hline
\end{tabular}

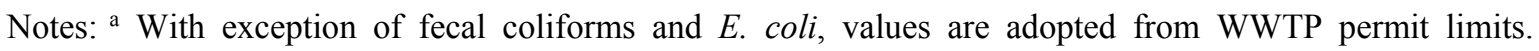
Monitoring is required, but no numeric limits on the constructed wetland treatment system are set; $\mathrm{WWTP}=$ wastewater treatment plant; $\mathrm{MO}=$ monthly average; $\mathrm{WK}=$ weekly average; $\mathrm{DA}=$ daily maximum. Source: USEPA [8,9].

Unlike conventional wastewater treatment facilities, CWs provide a variety of secondary ecosystem services in addition to their primary purpose for water quality improvement. These secondary ecosystem services make this technology an attractive solution to CSO pollution. The secondary services have been 
frequently cited to support inclusion of CWs in long-term CSO control plans $[13,14]$. Nevertheless, the value of secondary ecosystem services such as aesthetic quality and wildlife habitat in urban communities has not been quantified yet $[5,25]$.

\section{Design Challenges and Considerations for CSO Treatment in Constructed Wetlands}

Like stormwater wetlands, CSO CWs have to be designed to consider stochastic and intermittent event flows. Compared with stormwater, CSOs have higher concentrations of BOD, nitrogen, phosphorus, and fecal coliforms, as well as similarly high TSS concentrations (Table 1). The highly variable flow rate along with the higher loadings makes wastewater treatment plants with conventional treatment methods unfavorable for CSO treatment. CWs are ecologically engineered treatment systems with a great capacity to mitigate the variable flow and improve CSO water quality as discussed in Section 2.6. Compared with dry weather sewage flow and other less variable industrial wastewaters, nevertheless, CSO poses challenges to designing CWs to be event-fed and assessing their performance on an event basis. The following discussion is focused on the challenges to designing event-driven CSO CWs, without intention of a complete review. The CSO CWs in the US are taken as examples.

\subsection{NPDES Permitting}

The USEPA encourages NPDES permitting authorities to promote the shift to green infrastructure [1]. The IDEM has coordinated review of permit applications for a few $\mathrm{CW}$ wastewater treatment systems as alternatives for small residential and commercial developments [26]. The CSO CWs have been permitted by state permitting authorities as satellite facilities with separate outfalls from municipal wastewater treatment plants. The NPDES permit requirements for the existing CSO CWs in the US are summarized in Table 3. An Integrated Municipal NPDES Permit, which would bundle all requirements for a municipality (e.g., stormwater, CSOs, sanitary wastewater, and industrial effluent) into a single permit, has been under USEPA's consideration [4]. There were no numeric limits for the earlier Arch/Bar and Akron wetland treatment systems, but flow measurements or observations [8]. The recently-built Washington and Harbor Brook wetland treatment systems are subject to numeric limits of E. coli and fecal coliforms plus monitoring of flow and several water quality parameters. The parameters required for monitoring and reporting appear to be the same for the central wastewater treatment plants and wetland treatment systems. The Washington wetland treatment system was constructed after IDEM's CSO Treatment Policy was developed [27], which recommends additional requirements. The IDEM [27] requires effluent grab sampling of CSO treatment facilities. It states that effluent limits shall be imposed for $E$. coli and monitoring may be required for flow, BOD, TSS, ammonia, TP, pH, dissolved oxygen, and total residual chlorine if applicable. Metals monitoring may also be required on a case-by-case basis. The Harbor Brook CSO CW treatment system is not assigned numeric limits except for fecal coliforms for the first two years of pilot monitoring period [9]. However, the interim permit limitations require monitoring of both influent and effluent. The New York State Department of Environmental Conservation (NYSDEC) reserves the right to modify the permit to include additional limits for the monitoring parameters.

The Akron municipal wastewater treatment plant uses waste stabilization lagoons and discharge through its main outfall (001) to Tippecanoe River via Chippenwanuck Creek [8]. An agreed order in 
2003 [24] set effluent limits of CBOD5 (monthly average $10 \mathrm{mg} / \mathrm{L}$; weekly average $15 \mathrm{mg} / \mathrm{L}$ ), ammonia-N (monthly average $1.1 \mathrm{mg} / \mathrm{L}$ in summer and $1.6 \mathrm{mg} / \mathrm{L}$ in winter; weekly average $1.6 \mathrm{mg} / \mathrm{L}$ in summer and $2.4 \mathrm{mg} / \mathrm{L}$ in winter), TSS (monthly average $12 \mathrm{mg} / \mathrm{L}$; weekly average $18 \mathrm{mg} / \mathrm{L}$ ), and TP (daily average $1.0 \mathrm{mg} / \mathrm{L}$ ) for the Akron CSO CWs, which were more stringent than those for the Akron treatment plant's main outfall (001) and outfall (005) of another CSO treatment facility discharging to the Town Lake. However, these effluent limits in the agreed order are not covered by Akron's NPDES permit [8].

CWs are designed for a project life of 30-40 years [7]. CSO CWs should be designed to meet their discharge limits. There is no solid evidence from the existing CSO CWs to support consistent compliance with the limits for E. coli and fecal coliforms. The IDEM's CSO treatment policy [27] requires disinfection of effluent to meet the daily maximum $E$. coli concentration of $235 \mathrm{cfu} / 100 \mathrm{~mL}$, and dechlorination if necessary. Wildlife populations such as muskrats and waterfowl can substantially increase fecal coliform levels, especially in wetlands with standing water [7,28], making it difficult to consistently meet the permit limits without a disinfection measure. Chain fence and ribbon lines have been used in Harbor Brook to minimize disturbance from muskrats and birds. A second challenge to CSO CWs is to consistently meet the daily maximum and weekly average limits. CWs are natural treatment systems, which provide additional ecosystem services and are subjected to the diurnal and daily variations of environmental conditions such as temperature, dissolved oxygen, vegetation, and wild animal populations. Temporal variation in environmental conditions may result in greater variation in effluent quality compared with conventional treatment facilities. The fluctuation in wetland effluent quality associated with CSO event-feeding could be greatly decreased by the equalization function of pre-treatment facilities such as the storage tank and forebay pond that equalize CSO flow to the Washington CWs.

\subsection{Design Capacity}

The first step to design a CSO wetland treatment system is to determine the hydraulic capacity or event volume and peak flow rate of CSO flow to be accommodated by the proposed wetland treatment system. This step commences with an analysis of the frequency, duration, and intensity of storm events in the sewershed and the capacities of the existing sewer system and wastewater treatment facilities. Due to the complexity of combined sewer systems, it is normally necessary to use computer models, such as USEPA Stormwater Management Model and a number of proprietary computer models, to simulate combined sewer flows [2,29].

Containment of the CSO from at least a 5-yr or a 10-yr storm event is a typical baseline wetland volume [15]. The IDEM has issued permits to a number of CWs including CSO CWs [26]. The IDEM's CSO treatment policy [27] states that CSO treatment facilities should treat CSOs generated during storms no smaller than the 10-yr 1-h storm. The Washington CSO wetland treatment system demonstrates a second approach to CSO management: first flush is treated at a central wastewater treatment plant while the remaining CSO flows up to 10-yr 1-h storm events are treated in CWs [19]. A third approach is to divert first flush only for wetland treatment as with the Arch/Bar system [17]. Although the design storm frequency and duration is unknown, the Arch/Bar wetland actually discharged only twice from September 2007 to May 2014. The fine particles of peat and sand packed in its vertical flow wetland suggest that either it received only small volumes of first flush due to the low hydraulic conductivity of 
the peat and sand bed or it was designed to retain CSO in most of the events. The pilot wetland treatment system at Harbor Brook in New York adopted a low design capacity at 1-yr 2-h storms.

Lastly, it is noteworthy that the CSO CWs may actually receive more CSO than their design event volume. The CSO event volume overflow from the vortex separation unit to the Harbor Brook CWs and peak overflow rate were estimated with a Stormwater Management Model for an average year [21]. The peak flow in an average year, 204 $4077 \mathrm{~m}^{3} / \mathrm{h}$, will be below the design flow rate of $4485 \mathrm{~m}^{3} / \mathrm{h}$. However, the event overflow volumes, 22.7-6237 $\mathrm{m}^{3}$ event, could be much higher than the design CSO event volume of $2640 \mathrm{~m}^{3}$ (Figure 7). When a short return period or short storm duration is selected for design, there will be a higher chance that the wetland effluent does not meet the design targets. If a larger design volume were possible, however, treatment performance could be better while construction costs would be increased because most of the CSO events have smaller CSO volumes. A design value can be determined based on CSO size distribution in different hydrological years, permit conditions, and financially feasible long-term treatment goals.

\subsection{Evaluation of Hydraulic and Contaminant Loading}

Because of the highly varying flow rate of CSOs, hydraulic loading rate and retention time could not be reasonably estimated for CSO CWs. Consideration of hydraulic loading depth and event loading rates is therefore important to conceptualize CSO CW hydraulics in this review (Equations (1) and (2)). The Washington CWs have been designed with a CSO event hydraulic loading depth of $726 \mathrm{~mm} /$ event, being much higher than 26-78 mm/event at Arch/Bar and Akron CSO CWs. USEPA [16] recommends a typical hydraulic loading rate of $15-50 \mathrm{~mm} / \mathrm{d}$ to FWS CWs for secondary treatment of municipal wastewater. If the Washington wetlands were loaded continuously at this typical hydraulic loading rate, the design CSO volume would have to be loaded and retained in the CWs for 14.5-48.4 d between CSO events. Among the existing CSO wetland treatment systems, Harbor Brook has the greatest hydraulic loading at design event volume. When the three CWs are operated in series, the system will have a hydraulic loading depth of $841 \mathrm{~mm} /$ event and event hydraulic loading rate of approximately $331 \mathrm{~mm} / \mathrm{d}$, which is 6.6 times the normal hydraulic loading rate recommended by USEPA [16] for treatment of municipal wastewater in FWS wetlands. However, because Cell 1 will retain flow, water will be drawn from Cell 1 and dosed to Cell 2 at a rate of $150 \mathrm{~mm} /$ dose for a total of nine times during the 1-yr 2-h storm event [21].

$$
\begin{gathered}
D_{\text {event }}=1000 \times V_{\text {event }} / A_{s} \\
q_{\text {event }}=D_{\text {event }} / T_{\text {event }}
\end{gathered}
$$

where $D_{\text {event }}=$ CSO event hydraulic loading depth $(\mathrm{mm} / \mathrm{event}) ; V_{\text {event }}=$ design CSO event volume $\left(\mathrm{m}^{3}\right)$; $A_{s}=$ surface area of a constructed wetland $\left(\mathrm{m}^{2}\right) ; q_{\text {event }}=\mathrm{CSO}$ event hydraulic loading rate $(\mathrm{mm} / \mathrm{d})$; and $T_{\text {event }}=$ event length from the start of CSO loading to the end of recession at the design event volume (d).

The CSO event hydraulic loading rate as the Harbor Brook wetlands are operated in parallel will be $9600 \mathrm{~mm} / \mathrm{d}$ for the floating island wetland and $3675 \mathrm{~mm} / \mathrm{d}$ for the FWS wetland, which are much higher than the typical values of normal hydraulic loading rate for FWS CWs [7,16]. Guo et al. [30] found that the removal efficiencies of TP and ammonia in three pilot-scale subsurface flow wetlands in series for 
treatment of stormwater plus sewage decreased significantly when hydraulic loading rate was increased from 100 to $200 \mathrm{~mm} / \mathrm{d}$. At the relatively lower BOD5 concentrations of Harbor Brook CSO 018 (Table 1) it is estimated that the BODs loading rate will be $9.9-13.6 \mathrm{~g} / \mathrm{m}^{2} / \mathrm{d}$ for the three wetlands in series operation, $288-394 \mathrm{~g} / \mathrm{m}^{2} / \mathrm{d}$ for the floating island wetland in parallel operation, and $110-151 \mathrm{~g} / \mathrm{m}^{2} / \mathrm{d}$ for the FWS wetland in parallel operation. The USEPA [16] recommends a maximum BOD loading of only $6 \mathrm{~g} / \mathrm{m}^{2} / \mathrm{d}$ for FWS CWs to treat municipal wastewaters to attain an effluent BOD $<30 \mathrm{mg} / \mathrm{L}$. The Harbor Brook vertical flow wetland is designed with a hydraulic loading rate of $848 \mathrm{~mm} / \mathrm{d}$ on average of a 6-h cycle and approximately $2544 \mathrm{~mm} / \mathrm{d}$ during the dosing period when it is in series with the other two wetlands. Correspondingly, its average event $\mathrm{BOD}_{5}$ loading rate will be $25.4-34.8 \mathrm{~g} / \mathrm{m}^{2} / \mathrm{d}$, which is higher than that of the Minoa CWs in a fill-draw mode of operation in $1997,17.9 \mathrm{~g} / \mathrm{m}^{2} / \mathrm{d}$ [15]. When the wetlands are in parallel operation, the vertical flow wetland will have an event hydraulic loading depth of approximately $824 \mathrm{~mm} /$ event and an event hydraulic loading rate of $3594 \mathrm{~mm} / \mathrm{d}$, which is within an order of magnitude of the hydraulic conductivity of clean fine sand [15].

The high event hydraulic loading to the Harbor Brook CWs, especially in parallel operation, was due to the consideration that the floating island wetland will serve to some extent as a storage basin and the FWS wetland will provide polishing after treatment in the preceding wetlands, and that additional area for wetland construction was not available, based on site factors discussed later in Section 4. Lastly, typical hydraulic loading depth, event hydraulic loading rate, and contaminant event loading rates remain to be determined as more monitoring data are reported for CSO CWs.

\subsection{Pretreatment}

CSO has relatively high concentrations of TSS and floatables especially with first flush (Table 1). CWs are not typically designed for sediment removal or dredging, which may destroy plants and ecological integrity. Pretreatment is recommended to remove settleable solids and floatable materials [16]. Removing floatables prevents clogging of flow control structures and wetland medium beds and ensures the aesthetic value of green wetlands. Moreover, pretreatment facilities may equalize the variable CSO flows, smoothing both hydrographs and pollutographs.

All the CSO wetland treatment systems in the US have a pretreatment stage (Table 2). The Harbor Brook grit and floatable removal facility is estimated to remove $95 \%$ of all grit, sand, and sediment with specific gravity of 2.65 , greater than or equal to $300 \mu \mathrm{m}$ at the design peak flow of $4485 \mathrm{~m}^{3} / \mathrm{h}$ with an underflow rate of $612 \mathrm{~m}^{3} / \mathrm{h}$ [21]. Its vortex separation unit has an approximate volume of $127 \mathrm{~m}^{3}$. This pretreatment facility is estimated to divert as high as $91.0 \%$ of CSO volume to the wetlands while overflow to the wetlands is reduced to $78.5 \%$ of CSO events, indicating significant flow equalization. The IDEM's CSO treatment policy [27] states that CSO treatment facilities should retain flows generated during storms no smaller than the 1-yr 1-h storm for transportation to the wastewater treatment plant. Meanwhile, it requires at least 30 min of detention for TSS control with the 10-yr 1-h peak hourly flow and skimming of the detained flows to remove solids and floatables.

\subsection{Wetland Type}

Each type of CW can be designed to employ different combinations of layout, media, plants, flow sequence, and operating strategies so that the design targets are met with regard to the wastewater 
characteristics and local constraints. Several wetland types including FWS, horizontal subsurface flow, and vertical flow CWs have been used for stochastic and intermittent wastewater flows like CSO. In general, however, there are more FWS CWs than subsurface flow CWs in the US [16]. Due to the fact that their hydrologic characteristics are amenable to stormwater flows, FWS CWs are the preferred design concept for CSO treatment [15]. In contrast, European CSO wetland design is based broadly on the vertical flow type [12]. Van de Moortel et al. [31] compared surface and subsurface flow wetlands for CSO treatment and found that subsurface flow wetlands generally had lower effluent concentrations. The existing CSO wetland treatment systems in the US appear to have a small vertical flow wetland following a large FWS wetland (Table 2).

Likely because of the highly variable flow rate and pollutant loading over individual CSO events and across different sizes of events, four out of the five CSO wetland treatment systems in the US were designed with 2-3 stages of wetland treatment (Table 2). CWs are complex ecosystems with multiple components utilizing diverse natural and engineered processes. Each stage is perceived to make use of specific treatment processes and provide different ecosystem services and treatment functions. For example, it was envisioned that the key treatment element of the Arch/Bar CSO wetland is the deep vertical flow wetland, which enhances removal of nitrogen via nitrification and denitrification plus phosphate adsorption [17]. The water depth in the Harbor Brook floating island wetland is designed to vary between 0.3 and $1.5 \mathrm{~m}$. The expectation for this wetland to have a large storage capacity resulted in the selection of the floating island type [21]. With floating islands, plants will not become flooded for long periods of time while providing additional wildlife habitats and aesthetic value compared with open water zone of fringe wetlands. The deep water zones in the Harbor Brook FWS wetland are to help redistribute flow to reduce the potential for short-circuiting and provide reaeration and a refuge for waterfowl. Mosquito predators can also be maintained in the deep water zones.

\subsection{Wetland Layout}

Wetland layout determines the hydraulics for effective treatment. Stormwater wetlands tend to have irregular basins and channels adapted to local topography. CWs need greater hydraulic control for treatment of CSO than stormwater because of the higher pollutant loadings of CSOs. Although both complete-mix and plug-flow reactors are ideal design targets for different situations, plug-flow is preferred to produce a better effluent quality. Plug-flow can be approximated with long, narrow channels or 4-5 complete-mix reactors in series. To achieve laminar flow in plug-flow reactors, an aspect ratio (length to width) of 3-6 is typically recommended for conventional wastewater treatment reactors and CWs $[2,7,16]$.

The Minoa wetland cells have an aspect ratio of 2 [16], being outside the optimum range. When the six wetland cells were operated as horizontal subsurface flow wetlands in 1996, tracer studies found $<75 \%$ effective volume, significant short-circuiting, and dead zones [16]. Since then, it was changed to a fill-draw mode of operation. The Arch/Bar CSO FWS wetland has an aspect ratio of approximately 5.9 with clusters in the flow path center, which may help redistribute water across the width (Figure 3). The Washington CSO FWS wetland has a very large aspect ratio, approximately 31 (Figure 4). FWS wetland cells with an aspect ratio higher than 10 can produce significant operational problems at high hydraulic loading rates and/or with dense stands of emergent vegetation [16]. Head loss is exacerbated 
in totally vegetated FWS wetlands with a high aspect ratio [7]. The Harbor Brook floating island and FWS wetlands have aspect ratios of approximately 1.1 and 2.0, respectively (Figure 1). The small aspect ratio of the floating island wetland justifies its storage function and downgrades its treatment function.

\subsection{Configuration of Wetland Cells}

Wetland configuration plays an important role in determining hydraulics and functional treatment mechanisms. The properties of wetland elements (e.g., rooting substrate, packing material, biofilms, and plants) and their lateral and vertical configurations need to be explored so that proper mechanisms are instilled for removal of the target pollutants. Because of the larger peaking factor of CSOs, the existing CSO CWs in the US appear to have high hydraulic loading rates and short hydraulic retention time. Therefore, plant uptake of nutrients might be limited relative to physical removal mechanisms as reported by Borne et al. [32] for metal removal from stormwater in floating wetlands. Meanwhile, emergent plants in FWS wetlands and plant roots under floating islands may enhance sedimentation and filtration and provide microorganisms with solid surfaces to carry biofilms. In addition, presence of green plants provides additional ecosystem services such as wildlife habitats, aesthetics, and social acceptance of wastewater treatment by local residents.

Because of the fluctuating water depth in CSO CWs, plant species need to be carefully selected. The use of Typha or Scirpus would permit a temporary inundation of up to $1 \mathrm{~m}$ during peak storm events [15]. Typha species are drought-resistant and allow wetland bottom in an elevation without frequent groundwater upwelling. The use of Phragmites australis should be avoided in CSO CWs since it is commonly considered to be an invasive plant species in North America. One alternative solution to fluctuating water depth is to use floating island wetlands as adopted in the design of Harbor Brook wetland treatment system. Under different configurations certain wetland elements and treatment mechanisms are favored over the others. For example, the presence of plants in floating islands might increase filtration and sedimentation, whereas the same plants may bring in negative effects due to blocked sunlight, reduced surface reaeration, and increased waterfowl activity. In the designs of Arch/Bar and Harbor Brook CSO CWs, a number of native wetland species were evaluated for their tolerance to fluctuating hydroperiods [17,21]. The plant species selected also had flowering characteristics to enhance the aesthetic value of the facilities. Deeper micropools that could be recharged by groundwater have been included in the Arch/Bar, Washington, and Harbor Brook FWS wetlands to maintain wildlife habitats and mosque predators in dry weather conditions. The plants in vertical flow wetlands were chosen to tolerate long dry periods [21].

Water depth in CWs is usually regulated by the height of effluent weirs. Both the Arch/Bar and Harbor Brook CSO wetlands are installed with transducers to adjust the weir height [17,21]. A deep saturated zone provides more time for pollutant removal, but may tend to be anaerobic and slow down microbial activity. Deep water zones have been shown to improve FWS mixing characteristics to more closely approximate plug flow conditions [33]. In vertical flow wetlands for CSO treatment, ammonia is adsorbed to the packing media during the loading period and oxidized during the dry period [34]. Model simulations by Henrichs et al. [35] showed that at least $144 \mathrm{~h}$ of dry conditions are needed to fully regenerate retention soil filters for ammonia removal from CSOs. The Arch/Bar CSO wetland was designed to always have a saturated layer in the vertical flow wetland [17]. In contrast, there is no 
saturated layer in the Harbor Brook vertical flow wetland. There is a need to investigate the optimum combination of a permanently saturated layer and an overlying trickling layer for CSO treatment. France and Italy require a saturated layer of minimum $0.2 \mathrm{~m}$ [12]. Presence of a saturated zone has the potential to improve effluent quality because water contained in a saturated zone could be treated for a long time prior to the next CSO event and dilute CSO loaded in the next event. Amaral et al. [36] found 82\%-89\% of TSS removal and 1.9-2.4 $\log$ of E. coli reduction after $1 \mathrm{~d}$ of retention and increased removal efficiencies over the following $6 \mathrm{~d}$ despite slower removal in a pilot-scale horizontal subsurface flow CSO wetlands.

\subsection{Performance Assessment}

Unique methods have to be explored for performance assessment of CSO CWs regarding the two primary goals: flow mitigation and water quality improvement. Because of the stochastic and intermittent nature of CSOs, CSO CWs are rarely at a steady state and do not typically reach stable operation. To accurately assess the performance of CSO CWs both continuous flow metering and intensive sampling are needed. IDEM's CSO Treatment Facility Guidance [27] states that effluent composite sampling, either by automatic sampler or by grab samples, shall be initiated within $30 \mathrm{~min}$ from the beginning of a discharge event. The daily average shall be reported as the maximum daily concentration. The average of the daily averages shall be reported as the monthly concentration. Unlike the requirements in Indiana for monitoring of effluent only and reporting daily maximum and monthly average, the New York State permitting department requires reporting flow measurements and water quality monitoring results for both influent and effluent of the Harbor Brook CWs on an event basis [9]. Such compliance monitoring will provide a solid data base to quantify CSO CWs in flow retention, peak flow attenuation, and pollutant removal efficacy. Event-based reporting of monitoring results avoids over-weighing the first flush in a separate day and under-weighing active treatment over long recession.

The performance in water quality improvement can be better reflected by mass-based removal efficiency and removal rate on an event basis, rather than just by the daily difference between influent and effluent concentrations because the inflow and outflow rates are not constant. CSO CWs will act in a mixed operation mode when the actual CSO discharge is over its design capacity, i.e., batch reactor before fed to its maximum volume, then flow-through reactor at its maximum volume with continuous feeding and discharge, and finally batch reactor with discharge only. During smaller CSO events when the actual CSO volume is below the design event volume, the CSO discharge could be completely retained in the CWs, and wetland discharge would be dependent on the estimated volume set aside for the next CSO event. Therefore, the treatment performance of CSO CWs may be correlated with CSO event volume, event hydraulic loading depth, or event hydraulic loading rate. The statistical relationships of event mass removal rate and effluent concentration with CSO event volume, hydraulic loading, and pollutant mass loading shall be tested with monitoring results to support new designs.

\subsection{Development of Design Supportive Simulation Tools}

Computational simulation of CWs helps understand wetland internal processes. The improvement of existing approaches and the development of new models are moving on faster than ever before. Beyond describing treatment processes, the use of models supports the improvement of various CW designs and 
operational configurations. Whereas most $\mathrm{CW}$ models focus on detailed process descriptions and interactions, few other approaches aim to estimate treatment performance in a long-term view [37].

Modelling of CSO CWs is challenging in a specific way: Whereas the input data concerning domestic or industrial wastewater loads for CWs are relatively easy to describe, the CSO description itself requires computational simulation. For each CSO discharge point sewer models need to be used to describe the times, flow speeds and frequencies of hydraulic loads, as well as the pollutant loads in a long term. Sewer models were not developed for this purpose. From the viewpoint of a CSO CW the accuracy of sewer model estimates is quite low, and slight over- or under-estimations of impervious surfaces in a catchment area can cause huge differences in CSO quantities.

So far, CSO CWs in Europe have been dimensioned based only on hydraulic loads estimated from sewer simulations [12]. More than two decades of experience in Germany has showed that many filters are oversized, and the vegetation can suffer from water stress. Based on this, Meyer and Dittmer [29] developed the model RSF_Sim as the first (and so far only) example of dynamic estimation tools for CWs. It works as a part of sewer system models in order to display the performance of retention soil filters (RSFs), which means the specific German type of vertical flow CSO CWs. The model development was based on the evaluation of several monitoring data sets. Currently the option to handle measured input data is used to optimize the relatively simple approach. The RSF_Sim is under validation for the RSF like the national approach in France in order to become the mandatory tool for future CSO $\mathrm{CW}$ layout. Compared with the state-of-the-art design based solely on the hydraulic loads, the biggest advantage of the model RSF_Sim is reduced wetland surface areas and costs, plus determination of pollutant loadings.

This kind of estimation tool can be generally developed for all types of CWs, such as floating islands or FWS wetlands. The biggest hindrance is the lack of available datasets, and the comparability of similar, but not identical monitoring locations. The more diverse the systems are, the less possible it will be to unify the collected data. Performance estimation should not be based on a single system, even with available data of hundreds of feeding events.

\section{Adaptive Design of Harbor Brook CSO Wetland Treatment System}

For CSO long-term control plans incorporating green infrastructure approaches, an adaptive management approach can be employed during the implementation process [1]. Adaptive management means monitoring and evaluating green infrastructure projects and practices as work proceeds, and adapting or revising plans and designs as appropriate based on lessons learned. Harbor Brook CSO 018 Constructed Wetland Treatment Facility is the first and the only full-scale CSO wetland treatment system that adopted an adaptive design and management approach in the US, featuring three types of constructed wetlands and three flow sequences to be tested over two years of pilot study. The long term goal is to use the data generated from the full-scale pilot system to design a permanent wetland treatment system for CSO 018 with potential expansion to include CSO 078 and apply wetland treatment technology to other CSOs [21]. The intent of evaluating floating wetland island, vertical flow and FWS wetland technologies was to identify their respective performance characteristics, thereby establishing a flexible choice where one, two or three of the technologies might be sequenced to provide optimal treatment at other CSO locations, where sufficient land was available. 
Similar to most CSO treatment systems, the Harbor Brook CSO CW system is located within a fully-developed sewershed in an urban center. Consequently, multiple challenges were encountered during siting and permitting [21]. Federally regulated wetlands and a state and federally regulated stream (Harbor Brook) were located within the project area. The system was sited within a stormwater management basin used to manage flooding up to the 25-yr storm event. The CSO outfall had to be relocated to Harbor Brook to allow the majority of the flow from this CSO to enter the pilot wetlands for treatment before discharging to Harbor Brook. Construction of the wetland pilot treatment system required the relocation of a ditch with wetland vegetation. As a result, a total of eight permits were required from state, federal and local agencies. Because of the relatively novel treatment proposed, the permitting process required over one year and multiple information submittals to complete. Through impact minimization during siting, a relatively nominal mitigation of $809 \mathrm{~m}^{2}$ by replacement in-kind was required to compensate for displacement of jurisdictional wetlands.

Given the site location in the stormwater management basin in the floodplain of Harbor Brook, the wetland system is anticipated to flood infrequently. Under this circumstance, an inline check valve will isolate the CWs from Harbor Brook water filling the wetland discharge pipe. As water levels rise above the wetland controlled berm spillways in excess of the 10-yr storm interval, stormwater flows will enter and flood the wetland cells at different elevations intended to allow free flow and minimize erosion potential. Also because of its location within the stormwater detention basin, $9184 \mathrm{~m}^{3}$ of compensatory storage was excavated as part of the project to compensate for the loss of $8174 \mathrm{~m}^{3}$ of storage.

Vegetation has been fully established in the Harbor Brook CWs in summer 2014. Operation with CSO and monitoring are expected to begin in October 2014. By monitoring the effectiveness of the Harbor Brook CSO CWs, the design considerations and operating and monitoring plans can be optimized to meet CSO control goals. The operating experience and monitoring results will provide basis and insights to develop design considerations that could be transferable to other CSO discharge points.

\section{Conclusions}

CSO treatment wetlands have already been constructed and operated in Europe, but are relatively new in North America. CWs can not only remove pollutants, but also mitigate the event-associated flow regime. From a sustainability perspective we have shown that they are relatively less expensive to build than comparable grey infrastructure. CSO CWs could be a new and productive addition to the green infrastructure arsenal for application to North America, Europe and developing countries.

There are challenges to design CWs for CSO treatment, including permit provisions without consideration of the characteristics of green infrastructure, determination of design capacity for the highly variable CSO flows, need for pretreatment, and intensive monitoring required for adaptive design and performance assessment. In particular, there needs to have more and better monitoring data for effectiveness in meeting water quality parameters as well as provision for ecosystems services other than water quality improvement.

Simultaneous monitoring of flow rate and water quality for both inflow and outflow of CSO CWs has rarely been conducted and published, but required for performance assessment and needed to support design. Secondary ecosystem services, such as wildlife habitats, are frequently cited to support CSO CWs, though they have not been quantified yet. 


\section{Author Contributions}

Wendong Tao made the first draft of this manuscript. James Bays contributed information on the design of the Harbor Brook system. Daniel Meyer provided comparative information on European CSO CWs. Richard Smardon summarized sustainability of CSO CWs. Zeno Levy did the early identification and research of US CSO treatment wetlands. All authors contributed to the revisions and approved the final manuscript.

\section{Conflicts of Interest}

The authors declare no conflict of interest.

\section{References}

1. US Environmental Protection Agency (USEPA). Greening CSO Plans: Planning and Modeling Green Infrastructure for Combined Sewer Overflow (CSO) Control; Publication \# 832-R-14-001; USEPA: Washington, DC, USA, March 2014.

2. Metcalf \& Eddy/AECOM. Wastewater Engineering_Treatment and Resource Recovery, 5th ed.; McGraw-Hill Education: New York, NY, USA, 2014.

3. USEPA. Combined Sewer Overflow (CSO) Control Policy. Fed. Regist. 1994, 59, 18687-18698.

4. National Research Council (NRC). Urban Stormwater Management in the United States; National Academies Press: Washington, DC, USA, 2008.

5. Levy, Z.F.; Smardon, R.C.; Bays, J.S.; Meyer, D. A point source of a different color: Identifying a gap in United States regulatory policy for "green" CSO treatment using constructed wetlands. Sustainability 2014, 6, 2392-2412.

6. USEPA. Green Infrastructure Permitting and Enforcement Series: Factsheet 2 Combined Sewer Overflows; EPA832F12013; USEPA: Washington, DC, USA, 2013.

7. Kadlec, R.H.; Wallace, S.D. Treatment Wetlands, 2nd ed.; CRC Press: Boca Raton, FL, USA, 2009.

8. USEPA. Enforcement and Compliance History Online (ECHO): Facility Search-Enforcement and Compliance Data, 2014. Available online: http://echo.epa.gov/facility_search (accessed on 24 April 2014).

9. New York State Department of Environmental Conservation (NYSDEC). State Pollution Discharge Elimination System (SPDES) Discharge Permit Number NY 002 7081; NYSDEC: Syracuse, NY, USA, 4 June 2014.

10. Perreault, T.; Wraight, S.; Perreault, M. Environmental injustice in the Onondaga Lake waterscape, New York State, USA. Water Altern. 2012, 5, 485-506.

11. State University of New York College of Environmental Science and Forestry (SUNY ESF). Technical Memorandum: Harbor Brook CSO 018 Pre-Construction Monitoring; SUNY ESF: Syracuse, NY, USA, October 2012.

12. Meyer, D.; Molle, P.; Esser, D.; Troesch, S.; Masi, F.; Dittmer, U. Constructed wetlands for combined sewer overflow treatment-Comparison of German, French and Italian approaches. Water 2013, 5, 1-12. 
13. Volume 1: Final Integrated Overflow Control Plan; Prepared for Evansville Water and Sewer Utility; CH2MHILL: Evansville, IN, USA, 31 May 2013.

14. Save the Rain: Harbor Brook Wetland Project. Available online: http://savetherain.us/str_project/ wetland/ (accessed on 23 July 2014).

15. Crites, R.W.; Middlebrooks, E.J.; Bastian, R.K.; Reed, S.C. Natural Wastewater Treatment Systems; 2nd ed.; CRC Press: Boca Raton, FL, USA, 2014.

16. USEPA. Manual: Constructed Wetlands Treatment of Municipal Wastewaters; EPA/625/R-99/010; Office of Research and Development: Cincinnati, OH, USA, September 2000.

17. Umble, A.K.; Machlan, M.; Horvath, E.C.; Newvine, L.A. Constructed wetlands for treating combined sewer overflows: An alternative solution for implementing the CSO strategy. In Proceedings of the Water Environment Federation Watershed Management 2000 Conference, Vancouver, BC, Canada, 9-12 July 2000; Water Environment Federation: Alexandria, VA, USA, July 2000; pp. 2571-2588.

18. CDS Technologies, Inc. Small town finds cost-effective CSO solution. Water World 2003, 19, 22.

19. Harrison, M.L.; Kasthuri, L.P. How One Small Community Saved Big Bucks on Its CSO Long-Term Control Plan-City of Washington, Indiana; Bernardin, Lochmueller \& Associates, Inc.: Evansville, IN, USA, 2012.

20. Zagoudis, J. 2011 Top water \& wastewater projects. Water Wastes Digest, 14 December 2011, pp. 24-42.

21. Design Report: Harbor Brook CSO 018 Constructed Wetlands Pilot Treatment System; CH2MHILL and CHA: Syracuse, NY, USA, July 2011.

22. CH2MHILL; CHA. Harbor Brook CSO 018 Constructed Wetlands Pilot Treatment System, Drawings for Regulatory Agency Review; CH2MHILL and CHA: Syracuse, NY, USA, December 2012.

23. Giarrusso, S. Budgeting for operation and maintenance at a small plant: Village of Minoa case study. Clear Waters 2004, Winter, 44-45.

24. Indiana Department of Environmental Management (IDEM). Agreed Order between Indiana Department of Environmental Management (Complainant) and Town of Akron (Respondent), signed on 22 October 2003. Available online: http://www.in.gov/idem/oe/cause/AO/11554-W.htm (accessed on 5 August 2014).

25. Jaffe, M. Reflections on green infrastructure economics. Environ. Pract. 2011, 12, 357-365.

26. IDEM. Small Community Constructed Wetlands, Mound Systems. Available online: http://www.in.gov/idem/4893.htm (accessed on 25 July 2014).

27. IDEM. Agency Nonrule Policy Document: CSO Treatment Facilities (Water-016); IDEM Office of Water Quality: Indianapolis, IN, USA, April 2008.

28. Bell, S.; Gibson, J.P.; Frye, C. Moving the water quality needle: Effectiveness of the Banklick Creek Regional Wetland for water quality improvement as part of an integrated watershed approach to water resource management. In Proceedings of the Water Environment Federation Technical Exhibition and Conference (WEFTEC) 2013, Chicago, IL, USA, 5-9 October 2013; Water Environment Federation: Alexandria, VA, USA, October 2013; pp. 3133-3145. 
29. Meyer, D.; Dittmer, U. RSF_Sim-A simulation tool to support the design of constructed wetlands for combined sewer overflow treatment in Germany. Ecol. Eng. 2014, doi:10.1016/j.ecoleng.2014.10.032.

30. Guo, W.; Li, Z.; Cheng, S.; Liang, W.; He, F.; Wu, Z. Performance of a pilot-scale constructed wetland for stormwater runoff and domestic sewage treatment on the banks of a polluted urban river. Water Sci. Technol. 2014, 69, 1410-1418.

31. Van de Moortel, A.M.K.; Rousseau, D.P.L.; Tack, F.M.G.; Pauw, N.D. A comparative study of surface and subsurface flow constructed wetlands for treatment of combined sewer overflows: A greenhouse experiment. Ecol. Eng. 2009, 35, 175-183.

32. Borne, K.E.; Fassman-Beck, E.A.; Tanner, C.C. Floating treatment wetland influences on the fate of metals in road runoff retention ponds. Water Res. 2014, 48, 430-442.

33. Lightbody, A.; Nepf, H.; Bays, J. Modeling the hydraulic effect of transverse deep zones on the performance of short-circuiting constructed treatment wetlands. Ecol. Eng. 2009, 35, 754-768.

34. Woźniak, R. Interaction of oxygen concentration and retention of pollutants in vertical flow constructed wetlands for CSO treatment. Water Sci. Technol. 2007, 56, 31-38.

35. Henrichs, M.; Welker, A.; Uhl, M. Modelling of biofilters for ammonium reduction in combined sewer overflow. Water Sci. Technol. 2009, 60, 825-831.

36. Amaral, R.; Ferreira, A.; Galvao, A.; Matos, S. Constructed wetlands for combined sewer overflow treatment in a Mediteranean country, Portugal. Water Sci. Technol. 2013, 67, 2739-2745.

37. Meyer, D.; Chazarenc, F.; Claveau-Mallet, D.; Dittmer, U.; Forquet, N.; Molle, P.; Morvannou, A.; Pálfy, T.G.; Petitjean, A.; Rizzo, A.; et al. Modelling constructed wetlands: Scopes and aims-A comparative review. Ecol. Eng. 2014, in press.

(C) 2014 by the authors; licensee MDPI, Basel, Switzerland. This article is an open access article distributed under the terms and conditions of the Creative Commons Attribution license (http://creativecommons.org/licenses/by/4.0/). 